\title{
The 'WHO Safe Communities' model for the prevention of injury in whole populations (Review)
}

Spinks A, Turner C, Nixon J, McClure RJ

Spinks A, Turner C, Nixon J, McClure RJ.

The 'WHO Safe Communities' model for the prevention of injury in whole populations.

Cochrane Database of Systematic Reviews 2009, Issue 3. Art. No.: CD004445.

DOI: 10.1002/14651858.CD004445.pub3.

www.cochranelibrary.com 
TABLE OF CONTENTS

HEADER 1

ABSTRACT

PLAIN LANGUAGE SUMMARY

BACKGROUND

OBJECTIVES

METHODS

RESULTS

DISCUSSION

AUTHORS' CONCLUSIONS

ACKNOWLEDGEMENTS

REFERENCES

CHARACTERISTICS OF STUDIES

ADDITIONAL TABLES

APPENDICES

WHAT'S NEW

HISTORY

CONTRIBUTIONS OF AUTHORS

DECLARATIONS OF INTEREST

SOURCES OF SUPPORT

INDEX TERMS

1

2

3

3

3

5

10

11

11

12

15

21

24

24

24

25

25

25

25 
[Intervention Review]

\section{The 'WHO Safe Communities' model for the prevention of injury in whole populations}

Anneliese Spinks ${ }^{1}$, Cathy Turner ${ }^{2}$, Jim Nixon ${ }^{3}$, Roderick J McClure ${ }^{4}$

1School of Medicine, Griffith University, Meadowbrook, Australia. 2School of Nursing, University of Queensland, Herston, Australia.

${ }^{3}$ Department of Pediatrics and Child Health, University of Queensland, Herston, Australia. ${ }^{4}$ Accident Research Centre, Monash University, Victoria, Australia

Contact address: Anneliese Spinks, School of Medicine, Griffith University, University Drive, Meadowbrook, Queensland, 4031, Australia. a.spinks@griffith.edu.au.

Editorial group: Cochrane Injuries Group.

Publication status and date: Edited (conclusions changed), published in Issue 1, 2010.

Citation: Spinks A, Turner C, Nixon J, McClure RJ. The 'WHO Safe Communities' model for the prevention of injury in whole populations. Cochrane Database of Systematic Reviews 2009, Issue 3. Art. No.: CD004445. DOI: 10.1002/14651858.CD004445.pub3.

Copyright @ 2010 The Cochrane Collaboration. Published by John Wiley \& Sons, Ltd.

\section{A B S T R A C T}

\section{Background}

The World Health Organization (WHO) 'safe communities' approach to injury prevention has been embraced around the world as a model for co-ordinating community efforts to enhance safety and reduce injury. Approximately 150 communities throughout the world have formal 'Safe Communities' designation. It is of public health interest to determine to what degree the model is successful, and whether it reduces injury rates. This Cochrane Review is an update of a previous published version.

\section{Objectives}

To determine the effectiveness of the WHO Safe Communities model to prevent injury in whole populations.

\section{Search methods}

Our search included CENTRAL, MEDLINE and EMBASE, PsycINFO, ISI Web of Science: Social Sciences Citation Index (SSCI) and ZETOC. We handsearched selected journals and contacted key people from each WHO Safe Community. The last search was December 2008.

\section{Selection criteria}

Two authors independently screened studies for inclusion. Included studies were those conducted within a WHO Safe Community that reported changes in population injury rates within the community compared to a control community.

\section{Data collection and analysis}

Two authors independently extracted data. Meta-analysis was not appropriate due to the heterogeneity of the included studies.

\section{Main results}

We included evaluations for 21 communities from five countries in two geographical regions in the world: Austria, Sweden and Norway, and Australia and New Zealand. Although positive results were reported for some communities, there was no consistent relationship between being a WHO designated Safe Community and subsequent changes in observed injury rates.

\section{Authors' conclusions}

There is marked inconsistency in the results of the studies included in this systematic review. While the frequency of injury in some study communities did reduce following their designation as a WHO Safe Community, there remains insufficient evidence from which to draw definitive conclusions regarding the effectiveness of the model. 
The lack of consistency in results may be due to the heterogeneity of the approaches to implementing the model, varying efficacy of activities and strategies, varying intensity of implementation and methodological limitations in evaluations. While all communities included in the review fulfilled the WHO Safe Community criteria, these criteria were too general to prescribe a standardised programme of activity or evaluation methodology.

Adequate documentation describing how various Safe Communities implemented the model was limited, making it unclear which factors affected success. Where a reduction in injury rates was not reported, lack of information makes it difficult to distinguish whether this was due to problems with the model or with the way in which it was implemented.

\section{PLAIN LANGUAGE SUMMARY}

\section{The 'WHO Safe Communities' model for the prevention of injury in whole populations}

The World Health Organization (WHO) Manifesto for Safe Communities states that "All human beings have an equal right to health and safety". The emphasis of the Safe Communities approach is on collaboration, partnership and community capacity building to reduce the incidence of injury and promote injury-reducing behaviours. Approximately 150 communities throughout the world have been designated as 'Safe Communities', in countries as diverse as Sweden, Australia, China, South Africa and the Czech Republic. Programmes target highrisk groups or environments and promote safety for vulnerable groups. They range from bicycle helmet promotion in Sweden to antiviolence programmes in South Africa, traffic safety initiatives in South Korea and indigenous community injury prevention programmes in New Zealand.

The review authors identified that only 21 of the Safe Communities have been the subject of controlled injury outcome evaluations. These communities are from two geographical regions: the European countries of Austria, Sweden and Norway and the Pacific nations of Australia and New Zealand, both of which have relative economic wealth, higher health standards and lower injury rates than many other parts of the world. Although positive injury rate reductions were reported for some communities, the overall results varied substantially and overall do not provide a clear answer to the question of whether the adoption of the Safe Communities model leads to a significant reduction in injury. Limited information is available about how the programmes were implemented, their impact on injury risk factors and sustainability. There were also substantial methodology limitations associated with most of the included evaluations. No evaluations were available from other parts of the world, particularly those with lower economic and health standards. 


\section{B A C K G R O U N D}

The Manifesto for Safe Communities states that "All human beings have an equal right to health and safety" (WHO Safe Communities). The Safe Communities concept was introduced as a policy initiative during the First World Conference on Accident and Injury Prevention held in Stockholm, Sweden in September 1989. It arose as the celebrated response to a successful community approach to the problem of injury which had been implemented as a pilot project in the Swedish municipality of Falkoping in 1974 (WHO 1999). This project demonstrated a $23 \%$ decrease in total population injury rates, following an intervention which focused on specific injury related issues identified within the local community (Schelp 1987).

Since then, the Safe Communities approach has been embraced around the world as a model for co-ordinating communityoriented efforts to enhance safety and reduce injury (Svanstrom 1997; Sznajder 2002; Zhao 2003). The Safe Communities ideology engenders the notion that safety can be achieved through integrated, collaborative efforts that are implemented in a supportive social, cultural and political environment. Partnerships that unite various community members and groups are thus an essential component of the Safe Communities process. The official WHO Safe Communities Web site is available at http://www.phs.ki.se/csp/default.htm and describes the Safe Communities model in detail. This official site also provides details of all existing designated Safe Communities and Affiliate Safe Community Support Centres.

\section{The WHO Safe Community accreditation process}

Communities are eligible for international recognition and accreditation through the World Health Organization (WHO) if they meet the following six indicators:

- an infrastructure based on partnership and collaborations, governed by a cross-sectional group that is responsible for safety promotion in their community;

- long-term, sustainable programmes covering both genders and all ages, environments, and situations;

- programmes that target high-risk groups and environments, and programmes that promote safety for vulnerable groups;

- programmes that document the frequency and causes of injuries;

- evaluation measures to assess their programmes, processes and the effects of change; and

- ongoing participation in national and international Safe Communities networks (WHO Safe Communities).

Initially communities were expected to meet 12 criteria, but this has since been amended to the above six indicators which include an evaluation component. However, the required evaluation may consist of process/impact evaluation and may not necessarily include analysis of injury data which may be difficult for individual communities to access. Moreover, it is not a necessary prerequisite for a community to demonstrate injury rate reductions in order to be declared a Safe Community. However, designated Safe Communities must continue efforts to uphold the six indicators in order to retain their status. Since the designation process has started, more than 20 communities have had their WHO designation status revoked for not maintaining the necessary infrastructure and activities that underpin the Safe Community Model.

Since 1989, more than 140 communities in 25 different countries have been formally designated as 'Safe Communities', and over 100 communities are currently under preparation to be declared a Safe Community by WHO. These communities exist in many culturally diverse countries and regions including Scandinavia and Central Europe, Australia and New Zealand, China, Southern Asia, South Africa and North and South America. Not only do these regions differ in culture and lifestyles, but also in many other aspects that affect the predominant causes, types and prevalence of injury, including climate, geography and government. Each of these communities encounters unique issues and has specific injury related problems that need to be addressed. They are equipped with varying levels of resources and infrastructure with which to manage the injury problem. Further, the political environments in which these communities exist, as well as the attitudes of community members towards safety initiatives differ considerably.

By definition, each Safe Community is an individual programme with its own challenges to overcome. Specific injury prevention initiatives in the different communities range from bicycle helmet promotion in Skaraborg County, Sweden to anti-violence programmes in Eldorado Park, South Africa; traffic safety initiatives in Suwon, South Korea; and indigenous community injury prevention programmes in Waitekere, New Zealand. The unifying element within these programmes is the emphasis on collaboration, partnership and community capacity building that is the core of the Safe Community model.

\section{Why it is important to do this review}

Given the global interest in the Safe Community concept, it is of public health importance to determine the degree to which the model is successful in reducing injury rates in the communities to which it is introduced. Due to the long-term nature of the intervention within WHO Safe Communities, there are few published studies reporting injury rate outcomes and among those published there are conflicting findings. This systematic review will identify those studies conducted within WHO designated Safe Communities that have an evaluative component that includes a comparison with a control community to determine the effectiveness of the Safe Communities model in preventing injury. This review is an update of a previously published Cochrane Review (Spinks 2005).

\section{O B JECT IVES}

To determine the effectiveness of the WHO Safe Communities model to prevent injury in whole populations.

\section{METHODS}

\section{Criteria for considering studies for this review \\ Types of studies}

Any study that measures and reports changes in injury rates compared to a control community in a WHO designated Safe Community. (Designated Safe Communities are those that have undergone the formal WHO accreditation process on the basis of meeting the six eligibility criteria outlined in the Background section of this review). Study designs that are 'before and 
after studies' that compare changes between baseline and outcome measures for intervention communities (WHO Safe Community) with changes in these measures in comparable control communities and/or regions were included.

\section{Types of participants}

Whole populations within a community or specifically targeted subpopulations (e.g. children, the elderly).

\section{Types of interventions}

Community interventions based on the WHO Safe Community model that are aimed at reducing the incidence of injury, promoting injury-reducing behaviour or both. Interventions vary based on the needs of the communities and this review has included both those that are broad in focus and those that are targeted to specific injury outcomes (e.g. bicycle-related injury), specific age population subgroups or both.

\section{Types of outcome measures}

Objectively measured changes in injury rates (morbidity and mortality) for whole populations or specifically targeted population subgroups. We excluded studies reporting outcome measures based on self-report of injury from the review.

\section{Search methods for identification of studies}

The searches were not restricted by date, publication status or language.

\section{Electronic searches}

We searched the following databases:

- CENTRAL (The Cochrane Library 2007, Issue 3);

- MEDLINE (Ovid SP) 1950 to August (week) 2007;

- EMBASE (Ovid SP) 1980 to (week 34) August 2007

- PsycINFO (Ovid SP) 1806 to August (week 3) 2007;

- ISI Web of Science: Social Sciences Citation Index (SSCI) 1970 to August 2007

- ZETOC (searched August 2007)

The search strategies are reported in full in Appendix 1

The searches were updated by the authors, working independently from the Cochrane Injuries Group Editorial base, in December 2008 searching the following databases using the search terms 'Safe community' OR 'Safe communities'.

- CENTRAL (The Cochrane Library 2008, Issue 4);

- MEDLINE 1950 to December 2008;

- EMBASE 1980 to December 2008;

- CINAHL (1982 to December 2008);

- PsycINFO (1966 to December 2008).

\section{Searching other resources}

\section{Snowballing}

We checked reference lists of selected studies and relevant reviews and followed these up with a search of Citation Indexes.

\section{Safe Communities website}

The official website at http://www.phs.ki.se/csp/index_en.htm contains links to publications and designation applications documentation for each of the designated Safe Communities and we scanned this for relevant articles. However, for some communities this information is not current.

\section{Unpublished studies}

For the first Cochrane Review (published in 2005) we made attempts to contact a key person from each of the WHO designated Safe Communities to ensure that all published and unpublished reports were located. Contact was made by email after addresses were obtained from the Safe Communities website (http://www.phs.ki.se/csp/default.htm). We sent 54 emails in total and received 19 replies. For the update of this Cochrane Review, we contacted key personnel from each of the Safe Community Affiliate Support centres in an attempt to locate unpublished evaluations. This resulted in a number of responses directing the authors to various journal articles, reports and conference proceedings which were subsequently considered for this review.

\section{Data collection and analysis}

\section{Selection of studies}

An experienced author screened abstracts for relevance from electronic searches, lists of references and unpublished studies identified through personal contact with key persons from WHO designated Safe Communities.

Two authors independently assessed relevant studies selected from the process in Stage 1 against the inclusion criteria. Differences were resolved by discussion amongst all authors.

\section{Data extraction and management}

Two authors independently extracted data from the included studies using standardised forms. Data were available as measures of association (e.g. odds ratios, relative risks) and measures of percentage changes in injury rates that compared the Safe Community to a control community and linked programme interventions and changes in injury rates. Meta-analysis was not appropriate, due to the heterogeneous nature of the WHO Safe Community model, including duration of intervention and follow up, characteristics of the interventions and the demographics of the target populations. For all included studies, a detailed discussion of the findings along with a description of the exact intervention methods used is recounted in this review in Table 1.

Where a review author was also author of an included study, the other review authors extracted data for that study.

\section{Assessment of risk of bias in included studies}

The investigation of methods used in the implementation of community trials is a new field of exploration in injury research and few instruments to assess methodological quality are available. Traditional quality scoring was not undertaken. However, two authors independently performed a quality assessment process. This process was based on four of the seven criteria used for the quality assessment for controlled before and after designs, as described in the data collection checklist of the Cochrane Effective Practice and Organisation of Care Review Group (EPOC) (EPOC 2002). The criteria chosen are those that are relevant to community 
trial designs and specifically gauge the appropriateness of: baseline measurements, characteristics of the control site, protection against contamination between sites and reliability of outcome measures.

\section{RES U L T S}

\section{Description of studies}

\section{Results of the search}

There is a wealth of literature available relating to the WHO Safe Communities movement. The type and quality of publications available is widely varied among different communities, which reflects the differing availability of resources and expertise to perform methodologically sound evaluations. For a limited number of designated communities, evaluations of the injury prevention initiatives appear in peer reviewed scientific journals. Organisational and government reports are also available for several communities which describe the results of controlled evaluations. Although these reports are less likely to be peer reviewed, they are less constrained by space limitations and hence provide greater breadth of information relating to the implementation of interventions than do journal articles. Other literature pertaining to the WHO Safe Communities includes review articles, discussion pieces, conference proceedings, letters to the editor and newsletter articles.

After scanning the available literature, we considered 80 separate publications for the review, and selected 24 for inclusion. Twenty-one of theses publications pertained to nine individual communities: Falkoping, Sweden, Falun, Sweden, Lidkoping, Sweden, Motala, Sweden, Harstad, Norway, Vorarlberg, Austria, Shire of Bulla, Australia, New Plymouth, NZ and Waitakere, New Zealand. Additionally, three studies were included that collectively evaluated the Safe Community model in 1) all designated communities in Skaraborg County, Sw (a county in Sweden with five designated Safe Communities), 2) all designated communities in Sweden (14 communities) and 3) two communities in rural and remote Australia: Mt Isa and Mackay. Hence, this review is organised as a synthesis of 12 separate studies (some of which have more than one related publication.) These studies are described below and in Table 2 by community/region.

Thirty-five publications that were excluded described the following Safe Communities: Falkoping, Sweden (exc), Lidkoping, Sweden (exc), Motala, Sweden (exc), Skaraborg County (exc), Harstad, Norway (exc), Vaeroy, Norway, Penarth, Wales, BoulogneBillancourt, Fr, Dallas, USA, Fort McMurray, USA, LaTrobe, Australia, Illawarra, Australia, Shire of Bulla, Aus (exc), Waitakere, NZ (exc), Turanganui-a-kiwa, NZ, Rangiora \& Kawerau (New Zealand), Ngati Porou, New Zealand and Thinh Liet \& Co Nhue (Vietnam). Evaluation studies from these communities were excluded for the following reasons: no injury outcomes were assessed $(n=8)$; no community control was used as a comparison ( $=10)$; no baseline data were available for comparison $(n=2)$, the evaluation presented baseline injury data only $(n=4)$, data presented were contained in subsequent evaluations that were included $(n=5)$; the geographical region studied did not meet the criteria for a Safe Community $(n=4)$; the evaluation was a cost-benefit study $(n=1)$; or the evaluation was a critique reanalysing data presented and included previously $(n=1)$.

\section{Included studies}

Falkoping, Sweden, a municipality with 36,000 inhabitants, was the 'original' WHO Safe Community, awarded this distinction after the implementation of the Falkoping Accident Prevention programme (FAPP). The programme was initiated in 1975, although interventions targeting injuries did not begin until 1979 with the establishment of a cross-sectorial intervention group that operated at a county level. Over the ensuing decade, the intervention targeted traffic, childhood, home and work injuries and advocated community recognition and ownership of the injury problem. A local injury surveillance network was established to record injury data from health centres and emergency clinics. Hospitalisation data was also obtained from the Swedish National Board of Health and Welfare. One publication was included for Falkoping, which covered the time period from 1978 until 1992. This publication describes the activities of the intervention programme over 15 years. Injury rates are compared over that time with the entire county in which Falkoping is situated (Skaraborg County) and Sweden as a whole. The publication describes how the FAPP cross-sectorial intervention group was dissolved in 1982 and re-established in 1991 to coincide with the First International Conference on Safe Communities. The dissolution of the intervention group was in accordance with the original study design, and occurred in order that the responsibility for intervention activities would be removed from the county-level community health administration and would be absorbed by existing organisations at the local level. The rationale for this procedure was to test the ability of the community to carry the programme based on available local resources without external assistance. Therefore, from 1984 onward, programme activities were directed by the local Falkoping Health Committee as part of their general health promotion activities.

Lidkoping, Sweden was designated as a WHO Safe Community in 1989 following the implementation of the Lidkoping Accident Prevention programme which commenced in 1984. Lidkoping is a municipality in the county of Skarborg with approximately 36,000 inhabitants, and had initially been the control community for Falkoping when the first community based injury prevention programme was being trialed in Sweden. The Lidkoping Accident Prevention programme had a number of components designed to target a wide range of injuries in various subgroups of the population. Specific activities employed by the programme included the establishment of an interdisciplinary group to administer the programme, provision of safety related information to the public, training courses, a bicycle and traffic safety campaign including an infant car seat loan programme, and various ecological changes to remove environmental hazards. One publication that evaluated childhood injuries was selected to be included in the review. Injury rates were derived from hospital admissions data extracted from the National Swedish Hospital Discharge Register. One year of baseline data was available for the year 1983 prior to the programme commencement and seven years of follow-up data were available to 1991 . Three separate areas were chosen as control regions: 1) the four municipalities bordering Lidkoping (combined population of 42,000), 2) Skaraborg county as a whole, and 3) Sweden as a whole.

Falun, Sweden, a municipality in the county of Dalarna was designated as a WHO Safe Community in 1995. Falun has approximately 55,000 inhabitants. The injury prevention programme was initiated in 1989 when a cross-sectorial group 
was established to implement injury prevention initiatives focusing on five specific risk groups and environments. This crosssectorial group was then transformed in 1992 into a broader healthcare management group, which still focused on the five priority areas. These five areas were: injuries among children at home, injuries among elderly at home, traffic injuries, injuries at school and injuries in sports activities. Intervention activities consisted primarily of education, training, information provision, supervision and some environmental changes. Two publications which evaluated all injuries for all ages were included for this community. The first of these reported on injury related hospital admissions which were extracted from the national Swedish hospital discharge register and used to derive injury rates. Specific injury outcomes reported were home, work, traffic, sport and school injuries. Two years of baseline (1987 to 1989) and eight years of follow-up data (1989 to 1996) were available. The second study reported on outpatient injuries which were registered with a surveillance system implemented by nursing staff at the Falun County Hospital and five health care centres in the municipality. Data were available for three 12-month periods: 1989/90 (baseline), 1990/91 and 1994/95. Two regions served as control areas: Dalarna County (population 290,000) and Sweden as a whole (population approximately $8,800,000)$.

Motala, Sweden, in Ostergotland County, was designated as a WHO Safe Community in 1990. The Safe Community model was applied to this community, with specific activities including the establishment of a Child Safety Council, provision of injury prevention information to the public, safety maintenance of public places, demonstration of safety modifications to homes, safe cycling and safe travel programmes, and the inclusion of local sports clubs in the programme. Nine separate publications were included for this community, evaluating all injuries, injuries at home, childhood injuries, work-related injuries, injuries related to physical exercise, traffic injuries and injuries in the elderly. Evaluations were also included that examined the effect of socioeconomic status on injury occurrence. Injuries presenting to healthcare units were used in the analysis. Each of the publications used the same baseline and follow-up periods with one year of baseline data (1983 to 1984) and one year of follow-up data (1989). The control area was the municipality of Mjolby, also in Ostergotland County.

The Harstad Injury Prevention Study commenced in July 1985. Harstad, Norway, an Arctic municipality with 22,000 inhabitants, was designated as a WHO Safe Community in 1994, and again in 2003. The programme targeted a number of injuries in various subgroups of the population. Three separate publications were selected for inclusion in the review. These publications evaluated the following components of the programme: 1 ) burns and scalds in young children, 2) traffic injuries and 3) fractures in the elderly. The baseline and follow-up periods for the different publications varied as the programme components were initiated at different times. Injury rates were derived from emergency department presentations and hospital admissions recorded by a prospective hospital recording system. The burns and scalds component had a baseline period of 19 months and ten years of follow up from 1985 to 1995. The traffic injuries component had 2.5 years of baseline and 7.5 years of follow up, and the fractures in the elderly programme had three years of baseline and five years of follow up. The control region was Trondheim, a city with 134,000 inhabitants located 1000 km south of Harstad.
An analysis was undertaken of five designated Safe Communities in Skaraborg County, Sw: Lidkoping, Skovde, Mariestad, Falkoping and Tidaholm. The analysis considered all unintentional injuries occurring to children aged 14 years and younger which required hospital admission. Two different areas were used as comparative control regions: the rest of Skaraborg (10 municipalities) and the rest of Sweden.

An evaluative study was undertaken to measure the effectiveness of the Safe Community model for preventing injuries in all designated Safe Communities in Sweden (14 communities). These communities were designated between 1979 and 1995. Data were available for time series analysis from 1987 until 2002. Given that the Safe Community initiatives were staggered and the communities were designated over a 16-year time period, it was not possible to delineate a 'baseline' period as such for this study. It should be noted that the Safe Community process was already underway for some communities included in the analysis by the start of the available data period.

The Sichere Gemeinden Initiative in the county of Vorarlberg, Austria was initially piloted in 14 communities, beginning in 1993 and eventually expanded to the whole county in 1997 (designation 2002). Vorarlberg is one of nine provinces in Austria, with a population of 350,000 . The programme targeted injuries in the home, school and sporting/activity settings. Activities included media awareness campaigns, the dissemination of safety products, road safety education programmes and courses for in-line skating, mountain biking, skiing and snow-boarding. All injury data for the evaluation were provided by Statistik Austria and included injury related fatalities, hospital admissions and the number of hospital days attributed to injury. Data were available from 1993 until 2002/3. The control area for the study was the rest of Austria excluding Vienna, with a population of approximately 5,950,000.

The Safe Living programme in the Shire of Bulla, Australia was initiated in 1991 in an attempt to replicate the success of Swedish Safe Community efforts. The Shire of Bulla has a population of approximately 37,000 inhabitants and was officially designated as a WHO Safe Community in 1994. Interventions were driven by various working parties, 345 in total, whose membership included representatives from individuals and organisations both internal and external to the community. One hundred and thirteen activities of various durations that targeted many injury types and mechanisms were implemented during the first three years of the programme. These activities included media publicity, safety displays and promotions, subsidy and rebate schemes for safety equipment, training courses and ecological changes to remove environmental hazards. One publication evaluating the effect of the Safe Living programme on injuries and deaths in all ages was included in the review. This publication analysed data from various health and government data sets that detailed injury related deaths, hospital admissions and emergency department presentations. Five years each of baseline (1987 to 1991) and follow-up (1992 to 1996) data were available. The Shire of Melton (population 34,000), an outer district of Metropolitan Melbourne matched on demographic characteristics was selected as a control community.

Two communities in rural and remote Queensland (Mt Isa, Mackay, Australia) were selected by the state government to receive funding to implement childhood injury prevention interventions from 2002/03 until 2007/08. Mackay had been working towards 
designation as a WHO Safe Community since 1999 and was formally designated in 2004. Mount Isa began working towards WHO Safe Community designation at the onset of the child injury prevention project and will be formally designated in 2009. Both sites thus conducted their prevention activities within the Safe Community framework. Mackay is a regional coastal town with a population of 90,000 , and Mount Isa is a remote inland town with a population of 21,000 . Both Mackay and Mount Isa are served by publicly funded regional hospitals, and were chosen as intervention sites due to high paediatric injury rates relative to other regions in the state and the existence of emergency department and hospital admission injury surveillance systems. Although both communities have worked towards targeting injuries in other age groups, the analysis available for this review is directly related to the state government funded childhood injury prevention projects. These projects specifically aimed to reduce four types of injuries among children aged 0 to 4 years: falls, poisonings, drowning and burns. The intervention project was planned and directed by a Childhood Injury Prevention Project (ChIPP) Reference Group which provided guidance to local Working Groups and project officers located at both intervention sites. The ChIPP Reference Group consisted of senior representatives from key state government departments, university researchers and other relevant stakeholders with an interest in child safety. Available injury data included hospital admissions data provided by the Health Information Centre (Queensland Health) and Emergency department presentation data provided by the Queensland Injury Surveillance Unit. Both hospital and emergency department data were available for children aged 0 to 4 years from 1997/98 until 2005/06. Injury incidence rates were calculated and presented as time-trends before and after the intervention onset, with regression lines included to demonstrate underlying trends for the two periods. Two communities (Marreeba and Bundaberg) served as controls for the hospital admissions data, while the rest of the State of Queensland was used as a comparison for emergency department presentation data.

A coalition of organisations, groups and individuals was formed in New Plymouth, NZ to establish New Plymouth injurySafe (NPiS). New Plymouth is a district situated on the North Island of New Zealand with a population of approximately 66,600 in 2001 . The NPiS coalition started to form in 2001 when five separate local organisations formally agreed to meet regularly to co-ordinate injury prevention activities. Additionally, the New Plymouth district was selected as a site to receive funding and technical assistance from the Accident Compensation Corporation (ACC) in order to support a collaborative injury prevention project. Five key areas were identified as priority issues requiring inter-sectoral action: falls among older people, falls among children, road injuries and violence among youth, injuries to Maori and farm related injuries. Intervention activities focusing on these priority issues commenced in 2002, and New Plymouth was designated as a WHO Safe Community in 2005. Available data included 15 years of mortality data and 17 years of hospital admissions data from the New Zealand Health Information Service, emergency presentations data from the Taranaki District Health Board and data from the ACC on new entitlement claims. Trends in injury were assessed for New Plymouth compared with the whole of New Zealand. New Plymouth has a higher proportion of older people and a lower proportion of working age adults compared with the rest of New Zealand. Maori comprise $13 \%$ of the population which is slightly lower than the rest of New Zealand.
Waitakere, New Zealand, a city with approximately 156,000 inhabitants was designated as a WHO Safe Community in 1999 after implementation of the Waitakere Community Injury Prevention programme. This programme was initiated as a pilot project awarded to the Waitakere City Council by the New Zealand Public Health Commission as a response to the national injury programme. The programme targeted all injuries at all ages in the community, and injury rates were extracted from morbidity data for admissions to public and private hospitals (1989 to 1998). Injury hospitalisation rates were calculated using 1991, 1996 and 2001 census figures, and separate analysis was performed for children 0 to 14 years of age. Seven years of baseline (1989 to 1996) and five years of follow-up (1996 to 2001) data were available. The control area was a comparable community (population 147,000) matched on demographic characteristics, new housing developments, road safety and crime statistics. The rest of Auckland served as a second control region. There were two distinct phases of the intervention, a developmental phase which lasted for nine months and an ongoing implementation phase. Twenty-five percent of the Waitakere population are of Maori or Pacific Island descent and this was reflected in the composition of the project which had three major components for the Maori, Pacific and general populations. There were seven priority areas identified: Maori, Pacific, children, young people, older people, alcohol and road. Working parties were established for each priority area to drive intervention activities. Specific activities included promotion of child restraints, helmet and smoke alarm use, environmental hazard reduction and home safety education.

\section{Risk of bias in included studies}

Four of seven criteria outlined in the Data Collection Checklist described by the Cochrane EPOC Review Group were used to establish the methodological quality of included studies (EPOC 2002). These four criteria were:

- availability of baseline measurements;

- appropriate choice of control;

- protection against contamination between intervention and control site;

- reliability of outcome measures.

A fifth criterion, duration of follow up, was added by the authors.

Table 1 summarises the quality of the included studies against these criteria. The overall methodological quality was fair. None of the included evaluations achieved the top possible rating against all of the methodological criteria. Furthermore, there were additional issues explored in the Discussion of this review that may have limited the validity of the results.

It was difficult to determine the duration of baseline measurement for the two Swedish studies of combined communities (Skaraborg County, Sw and Sweden (14 communities)). This was because these studies involved multiple sites that had begun their injury prevention activities at different time points. Baseline measurements prior to programme commencement were sometimes measured for a period of one year duration only: Lidkoping, Sweden (childhood injuries evaluation), Motala, Sweden and Falkoping, Sweden. The baseline periods for the remaining communities varied from 19 months to 14 years. The limited duration of baseline data is problematic in that it is difficult to determine the true effect of the intervention without having 
established a valid starting point. Baseline levels may have been significantly under or over-estimated if the time period selected was unrepresentative of true injury rates. This is particularly a problem in small communities, where injury rates may fluctuate quite dramatically due to the relative rarity of specific events.

Duration of follow up varied from 1 to 14 years. The beginning of the follow-up period coincided with the start of the intervention for all except one community, Motala. For this community, the follow-up period was for one year only and occurred five years after the intervention period had begun. The relatively short duration of this follow-up period is problematic, in that this time period may not necessarily have represented the true injury pattern over the full time span of the intervention. The follow-up duration was considered to be adequate for the remaining communities.

Various methods were used to define control regions for the intervention communities. Several of the communities identified a particular geographically identifiable community as a control region: Harstad, Motala, Shire of Bulla, Mount Isa, Mackay and Waitakere. A combination of surrounding municipalities, the county and the whole country were employed to act as comparisons for changes in injury rates for the remaining communities (Lidkoping, Falkoping, Falun, Vorarlberg, New Plymouth).

The appropriateness of these various control measures is difficult to determine for some communities. Good attempts were made to match control communities selected for Motala, Waitakere, Mount Isa, Mackay and the Shire of Bulla on various demographic characteristics. For Harstad, however, the control community was selected on the basis that it was the only other Norwegian community for which longitudinal injury data was available. The size of the two communities was disparate $(22,000$ versus $135,000)$ and the geographical distance $(1000 \mathrm{~km})$ may have had significant demographic implications given that Harstad is located in a remote, northern region of Norway whilst Trondheim is located closer to other urban regions. The authors claim that the two communities were similar in demographic characteristics, including employment and age structure.

The use of surrounding municipality, whole county and whole country data as control regions has the advantage of comparing injury rate changes in the intervention community with local and national trends. At the same time, however, possible confounding influences inherent in the intervention area may not be accounted for. For example, higher socioeconomic status in Falun compared to the rest of Sweden. Similarly, Lidkoping was not identical to the surrounding municipalities selected as a control region for all predisposing factors that could be related to injury risk. Another limitation in selecting a surrounding region as a control comparison is the likely contamination of the control sites with intervention initiatives.

Little information was available to determine how effectively control communities had been protected against exposure to the interventions. It can be assumed that Trondheim, the control for Harstad received no exposure to the Safe Community intervention given the geographical distance between the two communities. The evaluation for the Shire of Bulla included a telephone survey to determine reach of the programme. This survey, which represented $2 \%$ of the total population, revealed that a small number of inhabitants in the control region had received some exposure to the intervention. No information was available for the remaining communities, however it is likely that contamination did occur for those that used neighbouring areas as control regions. National safety programmes outside the Safe Communities programme were mentioned in some of the evaluations, although detailed information about these interventions was not recorded. If contamination between sites did occur, the evaluation would most likely underestimate the effectiveness of the Safe Community model in preventing injury compared to a control.

All of the evaluations made use of objective injury data sources, however the reliability of the sources varied for the different communities. The most reliable sources for injury data are local surveillance systems which systematically capture outpatient data from either all or a representative sample of treatment facilities in the catchment area. The communities which employed injury surveillance systems were Falkoping, Motala, Harstad, Mount Isa, Mackay and the Shire of Bulla.

Less reliable are databases which record hospital discharge data for administrative purposes. Whilst administrative databases are often convenient and less costly for evaluation purposes, they are quite often unreliable and are subject to misclassifications that may arise due to changes in admission policies and diagnostic coding. Additionally, evaluations which rely on hospital discharge data may be insensitive to changes in the incidence of injuries of a less severe nature which nonetheless constitute a costly burden to emergency department and general practitioner services.

\section{Effects of interventions}

The results of the included studies are summarised below and in Table 2. The standard and method of injury outcome reporting varied greatly, hence the available statistical information differs between studies. Statistical significance was reported occasionally but not for all included studies. The time frame for the reported effect was also not consistent across the studies.

\section{Falkoping, Sweden}

From the beginning of the programme in 1978 until 1991, injury rates increased significantly in Falkoping by an average of $8.7 \%$ for females and $4.9 \%$ for males annually. Corresponding annual increases have been $4.7 \%$ for females and 3.0\% for males in Skaraborg county and $2.3 \%$ for females and $0.5 \%$ for males in Sweden. However, closer examination of the pattern of injury incidence from year to year reveals another picture. Initially, whilst the county-level cross-sectorial intervention group was operational, a decrease of 23\% in injury rates occurred. From 1983 onward however, coinciding with the break-up of this group, injury rates increased again at a rate higher than the rest of Sweden. The authors maintain that injury prevention efforts from 1983 were not conducted in the organised, co-ordinated manner typical of a Safe Community and that collaboration between the various sectors declined.

\section{Lidkoping, Sweden}

Childhood injury rates did not change significantly although linear regressions did reveal a downward trend (2.4\% for boys, $2.1 \%$ for girls) in the intervention region. A smaller trend occurred in the whole county $(1.0 \%$ for boys and $0.3 \%$ for girls) while injury rates increased (non-significantly) in the four bordering municipalities ( $0.6 \%$ for boys, $0.3 \%$ for girls). 
Motala, Sweden

An evaluation of all injuries found a decrease of $13 \%$ in Motala (OR $0.87,95 \% \mathrm{Cl} 0.84$ to 0.91 ) while the incidence remained unchanged in the control community. Closer examination by socioeconomic strata (household employment type) revealed that injury rates in the intervention area had decreased significantly among individuals residing in households with a significant member employed ( $P<0.001$ for men, $P<0.01$ for women), but not in households in which members were either non-vocationally active or self-employed. Injury rates among members of households with a significant member employed also decreased significantly in the control region $(P<0.05)$.

Additional evaluations examined the effect of the intervention on different types of injuries:

- childhood injuries decreased by $26 \%$ in Motala (OR $0.74,95 \% \mathrm{Cl}$ 0.68 to 0.81 ) and remained unchanged in the control community (OR $0.93,95 \% \mathrm{Cl} 0.82$ to 1.05 );

- injuries amongst the elderly decreased by $13 \%$ in Motala (OR $0.87,95 \% \mathrm{Cl} 0.77$ to 0.99 ) and remained unchanged in the control community (OR $0.98,95 \% \mathrm{Cl} 0.82$ to 1.18 );

- physical exercise related injuries decreased by $13 \%$ in Motala (OR $0.87,95 \% \mathrm{Cl} 0.79$ to 0.96 ) and remained unchanged in the control community (OR $0.93,95 \% \mathrm{Cl} 0.81$ to 1.07 ). Subgroup analysis by social strata showed that the intervention was more effective at reducing injuries among male members of households in which the significant member was either employed or self-employed. The intervention did not have any effect on physical activity related injury rates for females or members of vocationally inactive households;

- work related injuries decreased by $21 \%$ in Motala (OR 0.79 , $95 \% \mathrm{Cl} 0.70$ to 0.89 ) and remained unchanged in the control community (OR $1.08,95 \% \mathrm{Cl} 0.95$ to 1.23 );

- traffic injuries did not change in either Motala (OR 0.91, 95\% CI 0.81 to 1.02 ) or in the control community (OR $1.09,95 \% \mathrm{Cl} 0.91$ to 1.31 ).

- home injuries showed decreasing trends in Motala for males and females of all social strata compared with increased home injuries in the control area for all males and females except for females in non-vocationally active households.

Falun, Sweden

Hospital admissions: linear regression models were used to determine the effect of the intervention on targeted and 'most targeted', 'less targeted' and 'non-targeted' injuries. These linear regression parameters showed that there was no change in injury related hospitalisations for either 'most targeted' (Beta 0.072, 95 $\% \mathrm{Cl}-0.091$ to 0.235 ) or 'less targeted' (Beta $-0.104,95 \% \mathrm{Cl}-0.108$ to 0.316 ) injuries in the intervention area over the period of the intervention. Meanwhile, a significant increase occurred in 'most targeted' injuries in the control area, Dalarna county, (Beta 0.233, $95 \% \mathrm{Cl} 0.109$ to 0.379 ). The authors argue that the Safe Community intervention may have prevented a similar increase that may have otherwise occurred in Falun.

Outpatient injuries: the number of injury cases treated in outpatient setting decreased by $23.8 \%$ from baseline (1989/91) after five years (1994/95) compared with a $13.3 \%$ decrease in the bordering municipality control regions. Comparisons in injury rate reductions between the intervention and control region were reported for five specific injury types: home injuries, work injuries, school injuries, pedestrian/cyclist injuries and motor vehicle injuries. Chi ${ }^{2}$ tests were performed and showed that injury rates decreased significantly more in the intervention area than the control area for home and work injuries.

\section{Harstad, Norway}

Burns and scalds in children decreased in the intervention region (RR 0.49; $P=0.04$ ) whilst a non-significant increase and decrease occurred respectively in the two control regions: Trondheim RR 1.18 $(P=0.19)$, and six surrounding municipalities RR $0.60(P=0.32)$. The six surrounding municipalities were gradually exposed to the same interventions as occurred in Harstad during the intervention period.

Traffic injury rates in Harstad decreased by $26 \%$ following initiation of the intervention (RR $0.74,95 \% \mathrm{Cl} 0.63$ to 0.86 ). Meanwhile, in Trondheim traffic injuries increased by $9 \%$ (RR $1.09,95 \% \mathrm{Cl} 1.02$ to 1.15).

Overall fracture rates in the elderly did not change significantly in Harstad, although a downward trend did occur (RR 0.91, P = $0.2)$. Fracture rates did however increase significantly in the control community (RR 1.31, $\mathrm{P}<0.0001)$.

\section{Skaraborg County, Sw}

Changes in injury rates among the five designated WHO Safe Communities in Skaraborg County were mixed. Hospital admissions for injuries among children aged 14 years and younger decreased in Lidkoping over the study period (1987 to 2001), but showed no significant changes or increased in the other four communities. During the same time, hospital admissions for injuries decreased slightly in the rest of Skaraborg and increased significantly in the rest of Sweden. The results of the time-trend analysis modelling showed that trends in Lidkoping and Skovde differed significantly from those in the rest of Sweden, but in different directions: injury rates decreased in Lidkoping compared with the rest of Sweden $(P<0.001)$, but increased more in Skovde than the rest of Sweden $(P<0.001)$.

\section{Sweden (14 communities)}

Hospitalised injury rate reductions were achieved in seven of the 14 Safe Communities over the study time period (1987 to 2002), however this was offset by injury rate reductions in 12 of the 14 municipality control regions and a general reduction in Sweden as a whole by $5.14 \%$ during the time period. Thus, while five of the 14 Safe Communities outperformed their respective community control in injury rate reductions, nine performed less well than the control region.

\section{Vorarlberg, Austria}

Injury related deaths decreased in both Vorarlberg and the rest of Austria over the study time period (from 1993 to 2003). Although injury related fatality rates have fluctuated annually in Vorarlberg, the number of fatalities since 1993 have been less than the number that would have been expected in accordance with fatality rates in the rest of Austria. Injury related hospital admission rates increased in Vorarlberg from 1993 to 2002, however the associated number of hospital days in care decreased over the same period. As with fatalities, the days spent in hospital care were lower in Vorarlberg than would be expected in accordance with hospital care in the rest of Austria.

Shire of Bulla, Australia 
No significant changes in injury related deaths, hospitalisations or emergency department presentations occurred in either the intervention or control community. The authors suggest that low programme reach ( $1 \%$ to $27 \%$ for various components) may have been responsible for the lack of positive results.

\section{Mt Isa, Mackay, Australia}

Prior to the implementation of the childhood injury prevention intervention, injury related hospital admissions among children aged 0 to 4 years were decreasing in both the intervention and control communities (Bundaberg and Moreeba). In the postintervention period, hospital admissions continued to decrease in the intervention communities but increased in the control communities. Meanwhile, injury related emergency department presentations were increasing in both intervention and control areas (the rest of Queensland) prior to the intervention period. In the intervention areas emergency presentations decreased after the onset of the intervention while continuing to rise in the control regions.

\section{New Plymouth, NZ}

Due to small numbers, injury related deaths fluctuated in New Plymouth and so it was difficult to discern meaningful patterns following the onset of the interventions. Since 1989, injury related hospital admissions for the whole of New Zealand have been increasing, while they have remained reasonably constant in New Plymouth over the same time period (with some expected year to year fluctuation). Accordingly, injury rates were initially higher in New Plymouth compared with the rest of New Zealand, however from 1998 onwards, injury rates in New Plymouth have been less than those in the rest of the country. However, it is difficult to ascertain the contribution of the injurySafe collaboration to this trend, given that the NPiS coalition was not formed until 2001. It is possible that the activities implemented as part of the intervention have been responsible for maintaining the lower injury rate in New Plymouth compared with the rest of New Zealand since that time. Closer examination of annual hospital admission rates by age group revealed sharp drops in injury rates from 2003 to 2004 for children aged 0 to 9 years (35\% decline) and adolescents aged 10 to 19 years (although rates spiked again for this age group the following year), which may have been directly attributable to programme activities.

\section{Waitakere, New Zealand}

An initial evaluation of the Waitekere intervention was performed in 2001, three years after the implementation of the intervention. Logistic regression models revealed no significant differences between the communities for all injuries requiring hospital admission during the intervention/post-intervention period. Separate analysis for a paediatric subgroup ( 0 to 14 years), however, revealed a significant decrease in injury related hospital admissions for the intervention region compared with the control region $(P<0.05)$. Analysis of programme documentation revealed that intervention activities had primarily focused on child safety activities, which may explain why significant injury reductions were achieved in the paediatric population. A second evaluation was performed which included injury related hospital admissions data up until 2001. This analysis showed that injury related hospitalisations rose for Waitekere and in the two control regions, however the increase was of smaller magnitude in Waitekere compared to the control areas. This meant that while Waitekere had a higher rate of injury than both the whole of Auckland and the comparison community in 1996 (before the intervention began), the injury rate in Waitekere was lower than the two control areas in 2001. There was no reporting of significance testing for this difference.

\section{DISCUSSION}

There are several important findings from this review that relate to the key issues currently facing the science of community based injury prevention. These findings relate to the heterogeneity of approaches and implementation activities that have been conducted within the Safe Community framework, the relatively small number of evaluations conducted, methodological limitations inherent in community based evaluations, and the marked variation among different communities in the observed effect on injury outcomes.

It is evident from the information presented in accounts of the Safe Communities included within this review that despite all meeting the criteria for WHO accreditation, there was substantial heterogeneity of approaches and implementation activities. Most of the communities adopted bottom up community development methods, however some (e.g. Mount Isa and Mackay) involved substantial support from well resourced societal leadership. The other marked differences in the communities were the types of activities undertaken and the age and gender groups targeted.

Less than $15 \%$ of accredited WHO Safe Communities have been formally evaluated for injury outcomes. Those that have undertaken controlled analysis of observed injury rates represent five countries in two geographical regions of the world which enjoy relative economic wealth and higher health standards, including lower injury rates, than most other parts of the world. No evaluations were available from other parts of the world with either similar or lower economic and health standards, despite the designation of WHO Safe Communities, such as South Africa, Bangladesh, China, Vietnam, Canada, UK and the USA. Therefore, it is difficult to generalise these results to suggest that the Safe Communities model will necessarily reduce injury rates in these other communities. While the cost of evaluations can be great and is often given as the reason for not evaluating programmes, the cost of funding ineffective programmes is probably a greater drain on resources. It is important that large prevention programmes are routinely evaluated according to standard protocol.

There remains no standard accepted methodology for evaluating the effectiveness of any Safe Community and limitations existed for all of the included studies. In many studies there was a short duration of baseline and follow-up data collection periods meaning that the injury rates calculated for these periods may not have truly represented injury rates before and after programme implementation. Many studies were underpowered due to the small community population size. There was a reliance on administrative databases to ascertain injury rates, where the quality of these databases may not have reflected accurate injury incidence.

Although efforts were made in some of the included evaluations to match the control and intervention areas on a number of demographic characteristics, there may have been confounding influences (community factors related to injury outcomes) that were not accounted for in the analysis. For some evaluations, control areas were selected for convenience of available data and no attempt was made to match demographic characteristics, which 
may have affected the results. In particular, studies that used control regions which were much larger than the intervention areas may have introduced bias. The possibility of contamination between intervention and control sites was present in some cases, whereby individuals living in control areas may have been exposed to elements of the intervention. If contamination did occur, however, the effect of the intervention is likely to have been under-estimated and not over-estimated.

Another limitation in several evaluations was failure to take preexisting trends in injury rates into account, and the use of linear regression analysis to detect change over time which did not take into account social level confounders or the changing demographic characteristics of the denominator population. Extensive post-hoc subgroup analysis to identify specific sub-populations within the community where improvements in injury rates were observed is not recommended practice and may have contributed to the conflicting results, which were difficult to interpret overall. The effect of clustering was not taken into account in the included analyses which may have lead to over-optimistic assessments of the significance of effectiveness estimates.

Positive results are more likely to be published in the scientific literature than negative results. Efforts were made to contact Safe Community personnel to locate additional evaluations that may have met inclusion criteria. However, it is possible that evaluations exist which we were unable to locate. The study from Sweden that included 14 individual communities found that that the programmes for which reported evaluations exist were more successful in reducing injury than those with no publicly reported evaluations. This suggests that publication bias may be a significant problem.

The most striking feature of the review, however, is the marked variation in the extent to which designation as a Safe Community was associated with changes in injury outcomes. For some of the communities there was an unequivocal reduction in injury rates associated with achieving WHO Safe Community status. The reasons for the lack of positive findings in the others could be the results of a failed model, the use of non-efficacious interventions, or lack of intensity of implementation of the activities undertaken. On the basis of the papers published it is not possible to make any assessment as to whether negative results represented a failure of the model or a failure of the implementation of the model. Given the roughly equal distribution between successful and unsuccessful published evaluations, no definitive conclusion of the overall effectiveness of the Safe Communities model can be made.

The findings of this review are important given that there are 250 communities either designated or working toward designation as WHO Safe Communities. Nearly three times that number of programmes exist which use a similar model implemented under the banners of organisations such as the United States National Safe Kids, Safe Kids World-Wide and the Canadian Safe Communities Foundation. Given the complex nature of the model it is likely that barriers to complete delivery of the multifaceted interventions could frequently occur. Detailed reports/publications of the programme implementation processes, in addition to highquality evaluation of the overall programme effectiveness, is essential to build the evidence base for the Safe Community approach to injury prevention.

\section{AUTHORS' CONCLUSIONS}

\section{Implications for practice}

While the frequency of injury in some study communities did reduce following the designation as a WHO Safe Community there remains insufficient evidence from which to draw definitive conclusions regarding the effectiveness of the model. Practitioners working with WHO should recognise that safe community programmes are more likely to succeed if they include activities and strategies that have been independently demonstrated to be effective.

\section{Implications for research}

Knowledge about the success of the WHO Safe Community model for preventing injury is at a counterpoise. There is insufficient evidence to make a definitive statement regarding the effectiveness of the model, but enough positive evidence exists to warrant further evaluation using rigorous and consistent methodological techniques.

\section{ACKNOWLEDGEMENTS}

The research reported in this publication is a project of Injury Prevention and Control (Australia) Ltd. (http://www.ipca.com.au) supported by a grant from the National Health and Medical Research Council. The project was completed in conjunction with the Mt Isa and Mackay Child Injury Prevention Project supported by Queensland Health and Queensland Emergency Services. 


\section{RE F E R E N C E S}

\section{References to studies included in this review}

Falkoping, Sweden \{published data only\}

Svanstrom L, Schelp L, Ekman R, Lindstrom A. Falkoping, Sweden, ten years after: still a safe community?. International Journal for Consumer Safety 1996;3:1-7.

\section{Falun, Sweden \{published data only\}}

Bjerre B, Jonell A. The community safety approach in Falun, Sweden. What makes it work?. International Journal for Consumer and Product Safety 1998;5:139-53.

Bjerre B, Schelp L. The community safety approach in Falun, Sweden - is it possible to characterise the most effective prevention endeavours and how long-lasting are the results?. Accident Analysis and Prevention 2000;32:461-70.

\section{Harstad, Norway \{published data only\}}

Ytterstad B. A decade of community-based traffic injury prevention with emphasis on children. Postal dissemination of local injury data can be effective. International Journal of Circumpolar Health 2003;62:61-74.

Ytterstad B. The Harstad injury prevention study: community based prevention of fall-fractures in the elderly evaluated by means of a hospital based injury recording system in Norway. Journal of Epidemiology and Community Health 1996;50:551-8.

Ytterstad B, Smith GS, Coggan CA. Harstad injury prevention study: prevention of burns in young children by community based intervention. Injury Prevention 1998;4:176-80.

\section{Lidkoping, Sweden \{published data only\}}

Svanstrom L, Ekman R, Schelp L, Lindstrom A. The Lidkoping Accident Prevention Programme - a community approach to preventing childhood injuries in Sweden. Injury Prevention 1995;1:169-72.

\section{Motala, Sweden \{published data only\}}

Lindqvist K, Timpka T, Karlsson N. Impact of social standing on injury prevention in a World Health Organization Safe Community - intervention outcome by household employment contract. International Journal of Epidemiology 2004;33:605-11.

Lindqvist K, Timpka T, Schelp L. Evaluation of an interorganizational prevention program against injuries among the elderly in a WHO Safe Community. Public Health 2001;115:308-16.

Lindqvist K, Timpka T, Schelp L. Evaluation of interorganizational traffic injury prevention in a WHO safe community. Accident Analysis and Prevention 2001;33:599-607.

Lindqvist K, Timpka T, Schelp L, Ahlgren M. Evaluation of an inter-organizational program for prevention of work-related injuries in a WHO Safe Community. Work 1999;13:89-96.

Lindqvist K, Timpka T, Schelp L, Risto O. Evaluation of a child safety program based on the WHO Safe Community model. Injury Prevention 2002;8:23-6.
Timpka T, Lindqvist K. Evidence based prevention of acute injuries during physical exercise in a WHO safe community. British Journal of Sports Medicine 2001;35:20-7.

Timpka T, Lindqvist K, Ekstrand J, Karlsson N. Impact of social standing on sports injury prevention in a WHO safe community: intervention outcome by household employment contract and type of sport. British Journal of Sports Medicine 2005;39:453-7.

Timpka T, Lindqvist K, Schelp L, Ahlgren M. Communitybased injury prevention: effects on health care utilization. International Journal of Epidemiology 1999;28:502-8.

Timpka T, Nilsen P, Lindqvist K. The impact of home safety promotion on different social strata in a WHO safe community. Public Health 2006;120:427-33.

Mt Isa, Mackay, Australia \{published and unpublished data\} Davis E, Roselli T, McClure R. The Child Injury Prevention Project: a joint Department of Emergency Services and Queensland Health initiative. Final evaluation report March 2008.

\section{New Plymouth, NZ \{published data only\}}

McClellan V. New Plymouth District 2006 Community Injury Prevention Needs Assessment. Research and Evaluation Services Ltd: http://www.npis.org.nz/ needs_assessments/2001\%20IP\%20NEEDS \%20ASSESSMENT.pdf. September, 2006.

Shire of Bulla, Australia \{published data only\}

Ozanne-Smith J, Day L, Stathakis V, Sherrard J. Controlled evaluation of a community based injury prevention program in Australia. Injury Prevention 2002;8:18-22.

\section{Skaraborg County, Sw \{published data only\}}

De Leon AP, Svanstrom L, Welander G, Schelp L, Santesson P, Ekman R. Differences in child injury hospitalizations in Sweden: the use of time-trend analysis to compare various community injury-prevention approaches. Scandinavian Journal of Public Health 2007;35:623-30.

Sweden (14 communities) \{published data only\} Nilsen P, Ekman R, Stark Ekman D, Ryen L, Lindqvist K. Effectiveness of community-based injury prevention long-term injury rate levels, changes, and trends for 14 Swedish WHOdesignated Safe Communities. Accident Analysis and Prevention 2007;39:267-73.

Vorarlberg, Austria \{published and unpublished data\} Furian G, Rein F. 10 Year 'Safe Community', Evaluation Vorarlberg 2004. Sicher Leben.

Waitakere, New Zealand \{published data only\}

Coggan C, Lee M, Patterson P, Fill J. Safe Waitakere Injury Prevention: re-assessing the evidence. Injury Prevention Research Centre, University of Auckland: Centre Report Series No 74 2003, issue ISSN 1174-5371. 
Coggan C, Patterson P, Brewin M, Hooper R, Robinson E. Evaluation of the Waitakere Community Injury Prevention Project. Injury Prevention 2000;6:130-4.

\section{References to studies excluded from this review}

Boras, Swedem \{published data only\}

Ekman, R, Kaasik T, Villerusa A, Starkuviene S, Bangdiwala SI. Injury mortality in local communities in Sweden and in the three Baltic States: implications for prevention. International Journal of Injury Control and Safety Promotion 2007;14:153-61.

\section{Boulogne-Billancourt, $\mathbf{F r}$ \{published data only\}}

Sznajder M, Chevallier B, Leroux G, Bruneau C, Yacoubovitch J, Auvert $B$. Frequency of childhood injuries: first results of the Boulogne-Billancourt registry. Revue d'Epidemiologie et de Sante Publique 2001;49:125-34.

Sznajder M, Chevallier B, Yacoubovitch J, Aegerter P, Auvert B. Implementation of a system of surveillance of childhood injuries involved in a Safe Community program: the example of Boulogne-Billancourt (France). Injury Prevention 2002;8:330-1.

\section{Dallas, USA \{published data only\}}

Istre GR, McCoy MA, Womack KN, Fanning L, Dekat L, Stowe M. Increasing the use of child restraints in motor vehicles in a Hispanic neighborhood. American Journal of Public Health 2002;92:1096-9.

\section{Falkoping, Sweden (exc) \{published data only\}}

Schelp L. Community intervention and changes in accident pattern in a rural Swedish municipality. Epidemiology as a Basis of a Community Intervention Programme on Accidents (Thesis). Sundyberg, Sweden: Karolinska Institute, Department of Social Medicine, 1987.

\section{Fort McMurray, USA \{published data only\}}

Guidotti TL, Ford L, Wheeler M. The Fort McMurray demonstration project in social marketing: theory, design, and evaluation. American Journal of Preventive Medicine 2000;18:163-9.

\section{Harstad, Norway (exc) \{published data only\}}

Ytterstad B. The Harstad injury prevention study: hospitalbased injury recording used for outcome evaluation of community-based prevention of bicyclist and pedestrian injury. Scandinavian Journal of Primary Health Care 1995;13:141-9.

Ytterstad B. The Harstad injury prevention study: the characteristics and distribution of fractures amongst elders an eight year study. International Journal of Circumpolar Health 1999;58:84-95.

* Ytterstad B. The Harstad injury prevention study: the epidemiology of sports injuries. An 8-year study. British Journal of Sports Medicine 1996;30:64-8.

Ytterstad B, Sogaard, AJ. The Harstad Injury Prevention Study: prevention of burns in small children by a community-based intervention. Burns 1995;21:259-66.
Ytterstad B, Wasmuth $\mathrm{HH}$. The Harstad injury prevention study: evaluation of hospital-based injury recording and communitybased intervention for traffic injury prevention. Accident Analysis and Prevention 1995;27:111-23.

\section{Illawarra, Australia \{published data only\}}

Jeffs D, Booth D, Calvert D. Local injury information, community participation and injury reduction. Australian Journal of Public Health 1993;17:365-72.

\section{LaTrobe, Australia \{published data only\}}

Day L, Cassel E, Lough J. Latrobe Safe Communities: evaluation of a local level injury prevention program: 1996 - 2000. Monash University Accident Research Centre 2002; Vol. Report \#190.

Day L, Ozanne-Smith J, Cassell E, McGrath A. Latrobe Valley Better Health Project: evaluation of the injury prevention program 1992-1996. Monash University Accident Research Centre 1997; Vol. Report \#114.

Day LM, Ozanne-Smith J, Cassell E, Li L. Evaluation of the Latrobe Valley Better Health Injury Prevention Program. Injury Prevention 2001;7:66-9.

\section{Lidkoping, Sweden (exc) \{published data only\}}

Langley JD, Alsop JC. Lidkoping Accident Prevention Programme: what was the impact?. Injury Prevention 1996;2:131-4

Schelp L. The role of organizations in community participation - prevention of accidental injuries in a rural Swedish municipality. Social Science and Medicine 1988;26:1087-93.

Schelp L, Ekman R. Road traffic accidents in a Swedish municipality. Public Health 1990;104:55-64.

Schelp L, Ekman R, Fahl I. School accidents during a three school-years period in a Swedish municipality. Public Health 1991;105:113-20.

Svanstrom L, Ader M, Schelp L, Lindstrom A. Preventing femoral fractures among elderly: the community safety approach. Safety Science 1996;21:231-46.

\section{Motala, Sweden (exc) \{published data only\}}

Lindqvist $\mathrm{K}$, Lindholm L. A cost-benefit analysis of the community-based injury prevention programme in Motala, Sweden - a WHO Safe Community. Public Health 2001;115:317-22.

Lindqvist K, Timpka T, Schelp L. Ten years of experiences from a participatory community-based injury prevention program in Motala, Sweden. Public Health 1996;110:339-46.

Lindqvist K, Timpka T, Schelp L, Ahlgren M. The WHO Safe Community program for injury prevention: evaluation of the impact on injury severity. Public Health 1998;112:385-91.

Nolen S, Lindqvist K. A local bicycle helmet 'law' in a Swedish municipality - the effects on helmet use. Injury Control and Safety Promotion 2004;11:39-46. 
Ngati Porou, New Zealand \{published data only\}

Brewin M, Coggan C. Evaluation of the Ngati Porou Community Injury Prevention Project. Ethnicity and Health 2004;9:5-15.

Penarth, Wales \{published data only\}

Kemp A, Gibbs N, Vafidis G, Sibert J. Safe Child Penarth: experience with a Safe Community strategy for preventing injuries to children. Injury Prevention 1998;4:63-8.

\section{Rangiora \& Kawerau, NZ \{published data only\}}

Simpson JC, Morrison LGL, Langley JD, Ali Memon P. The process and impact of implementing injury prevention projects in smaller communities in New Zealand. Health Promotion International 2003;18:237-45.

\section{Shire of Bulla, Aus (exc) \{published data only\}}

Ozanne-Smith J, Sherrard J, Brumen I, Vulcan P. Community based injury prevention evaluation report - Shire of Bulla Safe Living Program. Monash University Accident Research Centre 1997; Vol. Report \#66.

Ozanne-Smith J, Watt G, Day L, Stahakis V. Community based injury prevention evaluation: the safe living program (1990-1996). Monash University Accident Research Centre 1999; Vol. Report \#131.

\section{Skaraborg County (exc) \{published data only\}}

Ekman R, Schelp L, Welander G, Svanstrom L. Can a combination of local, regional and national information substantially increase bicycle-helmet wearing and reduce injuries? Experiences from Sweden. Accident Analysis and Prevention 1997;29:321-8.

Ekman R, Welander $\mathrm{G}$. The results of 10 years' experience with the Skaraborg bicycle helmet program in Sweden. International Journal for Consumer and Product Safety 1998;5:23-39.

Ekman R, Welander G, Svanstrom L, Schelp L. Long-term effects of legislation and local promotion of child restraint use in motor vehicles in Sweden. Accident Analysis and Prevention 2001;33:793-7.

Thinh Liet \& Co Nhue, Vie \{published data only\}

Chuan LH, Svanstrom L, Ekman R, Lieu DH, Cu NO, Dahlgren G, et al. Development of a national injury prevention/safe community programme in Vietnam. Health Promotion International 2001;16:47-54.

\section{Turanganui-a-kiwa, NZ \{published data only\}}

Brewin M, Coggan C. Evaluation of a New Zealand indigenous community injury prevention project. Injury Control and Safety Promotion 2002;9:83-8.

\section{Vaeroy, Norway \{published data only\}}

Tellness G. An evaluation of an injury prevention campaign in Norway. Family Practice 1985;2:91-3.
Waitakere, NZ (exc) \{published data only\}

Harre N, Coveney A. School-based scalds prevention: reaching children and their families. Health Education Research 2000;15:191-202.

\section{Additional references \\ EPOC 2002}

Cochrane Effective Practice and Organisation of Care Review Group (EPOC). Data Collection Checklist.: 1.1.3 Controlled before and after study. Available from http:// www.epoc.cochrane.org/en/handsearchers.html July 2002.

\section{Schelp 1987}

Schelp L. Epidemiology as a basis of evaluation of a community intervention on accidents. Thesis. Sundyberg, Sweden: Karonlinska Institute, Department of Social Medicine, 1987.

\section{Svanstrom 1997}

Svanstrom L. More Safe Communities programs in Scandinavia have been evaluated: repeating the results from Falkoping. Injury Prevention 1997;3:230-1.

\section{Sznajder 2002}

Sznajder M, Chavallier B, Yacoubovitch J, Aegerter P, Auvert B. Implementation of a system of surveillance of childhood injuries involved in a Safe Community program: the example of Boulogne-Billancourt (France). Injury Prevention 2002;8:330-1.

\section{WHO 1999}

WHO Collaborating Centre on Community Safety Promotion at the Karolinska Institutet. The Safe Community Network (Monograph). Violence and Injury Prevention. World Health Organization 1999

\section{WHO Safe Communities}

WHO Safe Communities. Official website. Accessed January 2009.. http://www.phs.ki.se/csp/Default.htm.

\section{Zhao 2003}

Zhao Z, Svanstrom L. Injury status and perspectives on developing community safety promotion in China. Health Promotion International 2003;18:247-53.

\section{References to other published versions of this review Spinks 2005}

Spinks A, Turner C, Nixon J, McClure R. The 'Who Safe Communities' model for the prevention of injury in whole populations. Cochrane Database of Systematic Reviews 2005, Issue 2. [Art. No.: CD004445. DOI: 10.1002/14651858.CD004445.pub2]

* Indicates the major publication for the study 
CHARACTERISTICS OF STUDIES

Characteristics of included studies [ordered by study ID]

Falkoping, Sweden

\begin{tabular}{ll}
\hline Methods & Non-randomised, controlled community trial \\
\hline Participants & Intervention: Falkoping, Skaraborg County, Sweden (population 32,000) \\
& Control 1: Skaraborg County (population 266,000) \\
& Control 2: Sweden (population 8.6 million) \\
\hline Interventions & Falkoping Accident Prevention Program \\
\hline Outcomes & Injury rates determined from local injury surveillance system and hospital discharge data \\
\hline Notes & Year of WHO designation: 1991 \\
\hline
\end{tabular}

\section{Falun, Sweden}

\begin{tabular}{|c|c|}
\hline Methods & Non-randomised, controlled community trial \\
\hline \multirow[t]{3}{*}{ Participants } & Intervention: Falun, Dalarna County, Sweden (population 55,014) \\
\hline & Control 1: Dalarna County (population 292,103) \\
\hline & Control 2: Sweden (population 8.8 million) \\
\hline \multirow[t]{2}{*}{ Interventions } & WHO Safe Community model \\
\hline & $\begin{array}{l}\text { Specific activities included establishment of cross-sectorial group focusing on } 5 \text { risk groups and risk en- } \\
\text { vironments: } \\
\text { - injuries among children at home } \\
\text { - injuries among elderly at home } \\
\text { - traffic injuries (with focus on cycling and pedestrian injuries) } \\
\text { - injuries at school } \\
\text { - injuries in sports activities }\end{array}$ \\
\hline
\end{tabular}

$\begin{array}{ll}\text { Autcomes } & \text { Injury related hospital admissions extracted from the national Swedish hospital discharge register } \\ & \text { Specific injury outcomes reported: } \\ \text { - home } & \text { - work } \\ \text { - traffic } & \text { - sport } \\ \text { - school } \\ \text { B. Outpatient data registered with an injury surveillance system operating in Falun County Hospital and } \\ \text { 5 health centres in the municipality } \\ \text { Year of WHO designation: } 1995 \\ \text { Notes }\end{array}$


Harstad, Norway

\begin{tabular}{ll}
\hline Methods & Non-randomised, controlled community trial \\
\hline Participants & Intervention: Harstad, Norway (population 22,000) \\
& Control: Trondheim (population 134,000), located $1000 \mathrm{~km}$ from Harstad \\
\hline Interventions & Harstad Injury Prevention Study \\
& Specific activities included: \\
& - campaign to prevent burns and scalds in small children \\
& - campaign to reduce fall related fractures in the elderly \\
& - traffic injury prevention campaign \\
& - bicyclist and pedestrian injury prevention campaign \\
\hline Outcomes & Injury related emergency department presentations and hospital admissions recorded by a prospec- \\
tive hospital recording system \\
Specific injury outcomes reported: \\
- burn injuries in children \\
- fall fractures in the elderly \\
- traffic injury \\
- bicyclist and pedestrian injury
\end{tabular}

Lidkoping, Sweden

\begin{tabular}{ll}
\hline Methods & Non-randomised, controlled community trial \\
\hline Participants & Intervention: Lidkoping, Skaraborg County, Sweden (population 35,949) \\
& Control 1: 4 bordering municipalities (population 42,078) \\
Control 2: entire population of Skaraborg county \\
\hline
\end{tabular}

Interventions

Lidkoping Accident Prevention Programme

Specific activities included:

- establishment of interdisciplinary group to administer programme

- provision of safety related information to parents of small children

- infant car seat loan programme

- safe snow ploughing campaign

- training course to prevent sports injuries

- telephone hotline to advise public on specific safety issues

- bicycle safety campaign

- environmental changes, e.g. improving gym floors in schools

- traffic safety campaign

\begin{tabular}{ll}
\hline Outcomes & Injury related hospital admissions extracted from the national Swedish hospital discharge register \\
\hline Notes & Year of WHO designation: 1989 \\
\hline
\end{tabular}


Motala, Sweden

\begin{tabular}{|c|c|}
\hline Methods & Non-randomised, controlled community trial \\
\hline Participants & $\begin{array}{l}\text { Intervention: Motala, Ostergotland County, Sweden } \\
\text { Control: Mjolby, Ostergotland County }\end{array}$ \\
\hline Interventions & $\begin{array}{l}\text { WHO Safe Community model } \\
\text { Specific activities included: } \\
\text { - establishment of a Child Safety Council to implement regular safety measures } \\
\text { - provision of injury prevention information via mass media } \\
\text { - provision of age adjusted safety information to parents at compulsory annual health visits } \\
\text { - distribution of video demonstrating safety modifications in the home } \\
\text { - display of safety products and modifications in public places } \\
\text { - safety maintenance at day care, playgrounds, schools } \\
\text { - inclusion of local sports clubs in programme } \\
\text { - "Safe way to school" programme implemented at every primary school } \\
\text { - safe cycling programme implemented and bicycle helmets subsidised }\end{array}$ \\
\hline Outcomes & $\begin{array}{l}\text { Nature and extent of injuries presenting to health care units } \\
\text { Specific injury outcomes reported: } \\
\text { - childhood injury } \\
\text { - injuries in the elderly } \\
\text { - traffic injury } \\
\text { - acute injuries from physical exercise }\end{array}$ \\
\hline Notes & $\begin{array}{l}\text { Year of WHO designation: } 1990 \\
9 \text { publications were included }\end{array}$ \\
\hline
\end{tabular}

Mt Isa, Mackay, Australia

\begin{tabular}{ll}
\hline Methods & Non-randomised, controlled community trial \\
\hline Participants & Intervention: Mackay (population 90,000) and Mount Isa (population 21,000), Queensland, Australia \\
& Control 1: Mareeba (population 8400) and Bundaberg (population 45,800), Queensland, Australia \\
& Control 2: the rest of Queensland \\
& Childhood Injury Prevention Project (ChiPP) \\
& The following injury types were targeted for children aged 0 to 4 years: falls, burns, poisoning, drown- \\
& ing \\
Interventions & Specific activities included: \\
& - multi-strategic educational campaigns \\
- counselling sessions on child safety for new parents & - involvement of industry partners in safety awareness initiatives (including plumbers, electricians, \\
& nursery furniture retailers) \\
- promotion of safety products, e.g. smoke detectors, hot tap water regulators, stove barriers, child re- \\
sistant poison cabinets and storage cupboards \\
- promotion of removal of baby-walkers and unsafe nursery furniture
\end{tabular}


Mt Isa, Mackay, Australia (Continued)

Notes Year of WHO designation: Mackay - 2004; Mount Isa - 2009 (scheduled)

New Plymouth, NZ

\begin{tabular}{ll}
\hline Methods & Non-randomised, controlled community trial \\
\hline Participants & Intervention: New Plymouth, New Zealand (population 66,600) \\
& Control: New Zealand
\end{tabular}

Control: New Zealand

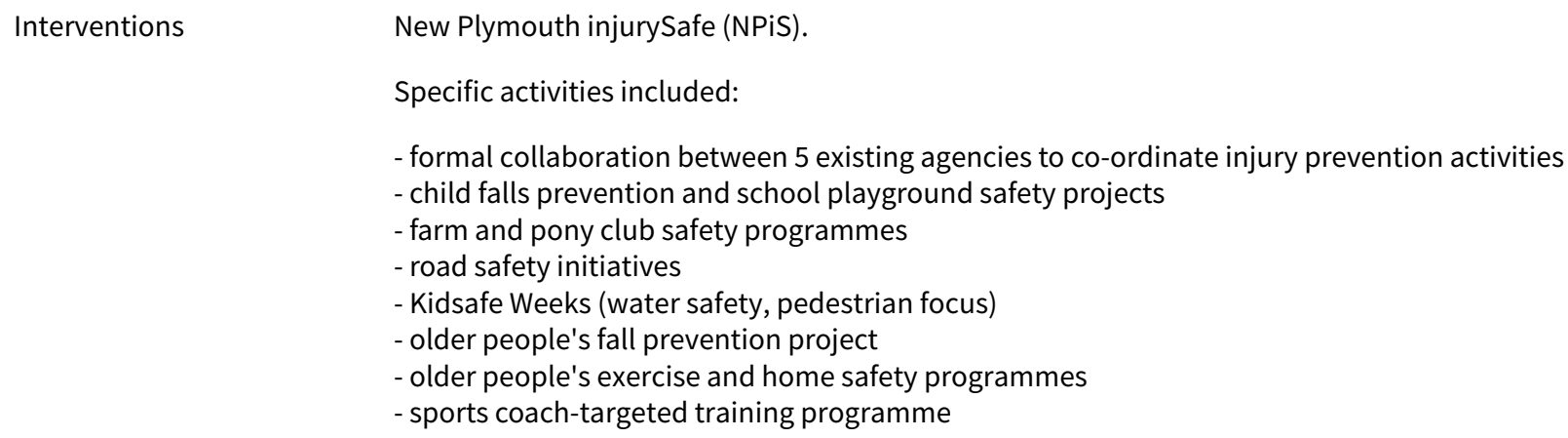

Notes Year of WHO designation: 2005

Shire of Bulla, Australia

\begin{tabular}{ll}
\hline Methods & Non-randomised, controlled community trial \\
\hline Participants & Intervention: Shire of Bulla, Australia (population 37,257) \\
& Control: outer metropolitan Melbourne (population 33,592). Matched on demographic characteristics. \\
\hline Interventions & Safe Living Programme \\
& Specific activities included: \\
& - publicity for the programme through local newspaper, newsletters, safety displays and promotions \\
& - subsidy and rebate schemes for safety equipment (smoke detectors, safety harnesses) \\
& - safety and first aid related education and training courses \\
& - school playground equipment audits \\
- home safety packages delivered to all households & - environmental changes to roads and paths
\end{tabular}

Outcomes

Injury related deaths, hospital admissions, emergency department presentations and self-reports

Sources of injury data included the Victorian Coroner's Facilitation System; the Victorian Inpatient Minimum Database, the Victorian Emergency Minimum Dataset and the Victorian Injury Surveillance System 
Skaraborg County, Sw

\begin{tabular}{ll}
\hline Methods & Non randomised, controlled community trial \\
\hline Participants & $\begin{array}{l}\text { Intervention: children aged } 14 \text { years and younger living in } 5 \text { Safe Communities in Skaraborg County } \\
\text { Control: children aged } 14 \text { years and younger living in 1) the rest of Skaraborg; 2) the rest of Sweden }\end{array}$ \\
\hline Interventions & $\begin{array}{l}\text { WHO Safe Community model implemented in } 5 \text { Safe Communities (Lidkoping, Skovde, Mariestad, } \\
\text { Falkoping, Tidaholm) }\end{array}$ \\
\hline Outcomes & Injury related hospital admission among children aged 14 years and younger \\
\hline Notes & $\begin{array}{l}\text { Year of WHO designation: Lidkoping - 1989; Falkoping - 1991; Skovde - 1996; Tidaholm - 1998; Mariestad } \\
-1999\end{array}$
\end{tabular}

Sweden (14 communities)

\begin{tabular}{ll}
\hline Methods & Non randomised, controlled community trial \\
\hline Participants & Intervention: residents of 14 Safe Communities throughout Sweden \\
& Control: residents of the rest of Sweden \\
\hline Interventions & WHO Safe Community model \\
\hline Outcomes & Injury related hospital admissions of at least 1 day duration \\
\hline
\end{tabular}

\section{Notes}

\section{Vorarlberg, Austria}

\begin{tabular}{ll}
\hline Methods & Non-randomised, controlled community trial \\
\hline Participants & Intervention: province of Vorarlberg, Austria (population 350,000) \\
& Control: the rest of Austria, excluding Vienna (population approx 5,950,000) \\
\hline
\end{tabular}

\begin{tabular}{ll}
\hline Interventions & Sichere Gemeinden Initiative: WHO Safe Community model \\
& Specific activities included: \\
& - media awareness campaigns \\
& - dissemination of safety product packages to mothers of newborns \\
& - road safety education programmes \\
& - in-line skating, mountain bike and snowboarding courses \\
& - fire protection and extinguishing training \\
\hline Outcomes & Injury related deaths, hospital admissions and hospital days (1993 to 2002) \\
& Injury data were sourced from Statistik Austria \\
\hline Notes & Year of WHO designation: 1998 (initially included 14 pilot communities, expanded to whole province \\
& 2002 )
\end{tabular}


Waitakere, New Zealand

Methods Non-randomised, controlled community trial

Participants Intervention: Waitakere, New Zealand (population 155,565)

Control 1: comparable community (population 147,000) matched on demographic characteristics, new housing developments, road safety, crime prevention

Control 2: rest of Auckland

\begin{tabular}{ll}
\hline Interventions & Waitakere Community Injury Prevention Project \\
\hline Outcomes & Injury deaths and hospital admissions (1989 to 2001) \\
& Separate analysis was performed for children 0 to 14 years of age \\
\hline
\end{tabular}

Notes Year of WHO designation: 1999

2 publications were included

\section{Characteristics of excluded studies [ordered by study ID]}

\begin{tabular}{ll}
\hline Study & Reason for exclusion \\
\hline Boras, Swedem & $\begin{array}{l}\text { No community control was used as a comparison for injury outcomes. Although this publication } \\
\text { did present data from } 3 \text { communities in the Baltic States, these communities were not considered } \\
\text { comparable as controls for a community in Sweden }\end{array}$ \\
\hline Boulogne-Billancourt, Fr & 2 publications were excluded; they both present baseline injury data only \\
\hline Dallas, USA & No injury outcomes were assessed \\
\hline Falkoping, Sweden (exc) & Data were also presented in a subsequent publication that was included \\
\hline Fort McMurray, USA & No injury outcomes were assessed \\
\hline Harstad, Norway (exc) & $\begin{array}{l}5 \text { publications were excluded. No community control was used as a comparison for 3. } 2 \text { were earlier } \\
\text { publications of data that were presented in subsequent publications. }\end{array}$
\end{tabular}

\begin{tabular}{ll}
\hline Illawarra, Australia & No community control was used as a comparison for injury outcomes \\
\hline LaTrobe, Australia & $\begin{array}{l}\text { 3 publications were excluded. No community control was used as a comparison for 2. No baseline } \\
\text { data were available for the third. }\end{array}$ \\
\hline Lidkoping, Sweden (exc) & $\begin{array}{l}5 \text { publications were excluded. } 1 \text { was a critique reanalysing data presented previously. } 1 \text { did not as- } \\
\text { sess injury outcomes. } 1 \text { did not present baseline data for the outcome being assessed. } 2 \text { presented } \\
\text { baseline data only. }\end{array}$ \\
\hline
\end{tabular}

Motala, Sweden (exc)

4 publications were excluded. 2 had no appropriate community control used as a comparison. 1 did not assess injury outcomes. 1 was a cost-benefit analysis and did not present changes in injury incidence.

Ngati Porou, New Zealand The community was not a WHO designated Safe Community




\begin{tabular}{ll}
\hline Study & Reason for exclusion \\
\hline Penarth, Wales & No injury outcomes were assessed \\
\hline Rangiora \& Kawerau, NZ & No injury outcomes were assessed \\
\hline Shire of Bulla, Aus (exc) & $\begin{array}{l}\text { 2 publications were excluded. They both presented data that were in a subsequent publication that } \\
\text { was included. }\end{array}$ \\
\hline Skaraborg County (exc) & $\begin{array}{l}\text { 3 publications were excluded. The geographical area being studied (Skaraborg county) did not } \\
\text { meet with the definition for a Safe Community. }\end{array}$ \\
\hline Thinh Liet \& Co Nhue, Vie & No injury outcomes were assessed \\
\hline Turanganui-a-kiwa, NZ & No community control was used as a comparison \\
\hline Vaeroy, Norway & No community control was used as a comparison \\
\hline Waitakere, NZ (exc) & No injury outcomes were assessed \\
\hline
\end{tabular}

\section{ADDITIONAL TABLES}

Table 1. Methodological quality of included studies

\begin{tabular}{|c|c|c|c|c|c|c|}
\hline $\begin{array}{l}\text { Safe } \\
\text { Commu- } \\
\text { nity }\end{array}$ & $\begin{array}{l}\text { Baseline } \\
\text { measure- } \\
\text { ment }\end{array}$ & $\begin{array}{l}\text { Fol- } \\
\text { low-up } \\
\text { duration }\end{array}$ & Control community & $\begin{array}{l}\text { Protection of } \\
\text { sites }\end{array}$ & $\begin{array}{l}\text { Outcome reliabil- } \\
\text { ity }\end{array}$ & Outcome \\
\hline Falkoping & 1 year & 14 years & $\begin{array}{l}\text { 1) Whole county } \\
\text { 2) Sweden }\end{array}$ & No information & $\begin{array}{l}\text { Local injury sur- } \\
\text { veillance }\end{array}$ & $\begin{array}{l}\text { Hospital admis- } \\
\text { sions }\end{array}$ \\
\hline Lidkoping & 1 year & 8 years & $\begin{array}{l}\text { 1) Bordering municipali- } \\
\text { ties } \\
\text { 2) Whole county } \\
\text { 3) Sweden }\end{array}$ & No information & $\begin{array}{l}\text { Administrative } \\
\text { database }\end{array}$ & $\begin{array}{l}\text { Hospital admis- } \\
\text { sions }\end{array}$ \\
\hline Falun & 2 years & 8 years & $\begin{array}{l}\text { 1) Whole county } \\
\text { 2) Sweden }\end{array}$ & No information & $\begin{array}{l}\text { Administrative } \\
\text { database } \\
\text { Injury surveillance } \\
\text { system }\end{array}$ & $\begin{array}{l}\text { Hospital admis- } \\
\text { sions } \\
\text { Outpatient in- } \\
\text { juries }\end{array}$ \\
\hline Motala & 1 year & 1 year & $\begin{array}{l}\text { Community matched on } \\
\text { demographic characteris- } \\
\text { tics }\end{array}$ & No information & $\begin{array}{l}\text { Local injury sur- } \\
\text { veillance }\end{array}$ & $\begin{array}{l}\text { All presentations } \\
\text { to health care } \\
\text { units }\end{array}$ \\
\hline $\begin{array}{l}\text { Skaraborg } \\
\text { Country }\end{array}$ & NA & NA & $\begin{array}{l}\text { 1) Rest of Skaraborg } \\
\text { 2) Rest of Sweden }\end{array}$ & No information & $\begin{array}{l}\text { Administrative } \\
\text { database }\end{array}$ & $\begin{array}{l}\text { Hospital admis- } \\
\text { sions }\end{array}$ \\
\hline $\begin{array}{l}14 \\
\text { Swedish } \\
\text { communi- } \\
\text { ties }\end{array}$ & NA & NA & Rest of Sweden & No information & $\begin{array}{l}\text { Administrative } \\
\text { database }\end{array}$ & $\begin{array}{l}\text { Hospital admis- } \\
\text { sions }\end{array}$ \\
\hline
\end{tabular}


Table 1. Methodological quality of included studies (Continued)

\begin{tabular}{|c|c|c|c|c|c|c|}
\hline Harstad & $\begin{array}{l}19 \\
\text { months - } \\
3 \text { years }\end{array}$ & 5-10 years & $\begin{array}{l}\text { Larger community not } \\
\text { matched on demographic } \\
\text { characteristics }\end{array}$ & Good & $\begin{array}{l}\text { Local injury sur- } \\
\text { veillance }\end{array}$ & $\begin{array}{l}\text { Hospital admis- } \\
\text { sions } \\
\text { ED presentation }\end{array}$ \\
\hline
\end{tabular}

\begin{tabular}{|c|c|c|c|}
\hline $\begin{array}{l}\text { Shire of } \\
\text { Bulla }\end{array}$ & 5 years & 6 years & $\begin{array}{l}\text { Community matched on } \\
\text { demographic characteris- } \\
\text { tics }\end{array}$ \\
\hline
\end{tabular}

$\begin{array}{ll}\begin{array}{l}\text { Telephone survey } \\ \text { revealed some ex- } \\ \text { posure to inhabi- }\end{array} & \begin{array}{l}\text { Administrative } \\ \text { database }\end{array} \\ \begin{array}{l}\text { tants in control re- } \\ \text { gion }\end{array} & \begin{array}{l}\text { Local injury sur- } \\ \text { veillance system }\end{array}\end{array}$

Deaths

Hospital admission

ED presentations

Mount Isa, 5 years 4 years
Mackay

\section{1) 2 communities matched on demographic charac- teristics}

2) The rest of the state
Geographical distances between communities would ensure good protection against contamination. Household safety surveys were conducted in both intervention and control communities at baseline and post-intervention. These revealed increased safety precautions in both areas that were more marked in the intervention sites.

\section{Administrative} database

Local injury surveillance system
Hospital admissions

ED presentations

$\begin{array}{llll}\begin{array}{lll}\text { Vorarl- } \\ \text { berg }\end{array} & 0 \text { to } 3 & 7 \text { to } 11 & \begin{array}{l}\text { The rest of Austria exclud- } \\ \text { ing Vienna }\end{array}\end{array}$

No information. There are no other WHO Safe Communities in Austria except for Vienna.

\begin{tabular}{ll}
$\begin{array}{l}\text { Administrative } \\
\text { database }\end{array}$ & $\begin{array}{l}\text { Deaths } \\
\text { Hospital admis- } \\
\text { sions } \\
\text { Hospital days }\end{array}$ \\
\hline $\begin{array}{l}\text { Administrative } \\
\text { database }\end{array}$ & $\begin{array}{l}\text { Deaths } \\
\text { Hospital admis- } \\
\text { sions } \\
\text { ED presentations }\end{array}$
\end{tabular}

\begin{tabular}{|c|c|c|c|c|c|c|}
\hline $\begin{array}{l}\text { New Ply- } \\
\text { mouth }\end{array}$ & 12 years & 5 years & The whole of New Zealand & $\begin{array}{l}\text { No information: } \\
\text { other communi- } \\
\text { ties within New } \\
\text { Zealand are desig- } \\
\text { nated WHO Safe } \\
\text { Communities and } \\
\text { may have imple- } \\
\text { mented similar ac- } \\
\text { tivities during the } \\
\text { study period }\end{array}$ & $\begin{array}{l}\text { Administrative } \\
\text { database }\end{array}$ & $\begin{array}{l}\text { Deaths } \\
\text { Hospital admis- } \\
\text { sions } \\
\text { ED presentations }\end{array}$ \\
\hline Waitakere & 8 years & 5 years & $\begin{array}{l}\text { 1) Community matched on } \\
\text { demographic characteris- } \\
\text { tics } \\
\text { 2) Rest of Auckland }\end{array}$ & No information & $\begin{array}{l}\text { Administrative } \\
\text { database }\end{array}$ & $\begin{array}{l}\text { Deaths } \\
\text { Hospital admis- } \\
\text { sions }\end{array}$ \\
\hline
\end{tabular}

\section{$\mathrm{ED}=$ Emergency Department}

$\mathrm{NA}=$ not applicable 
Table 2. Summary of results

\begin{tabular}{|c|c|c|c|}
\hline $\begin{array}{l}\text { Safe Com- } \\
\text { munity }\end{array}$ & $\begin{array}{l}\text { Reported statistical } \\
\text { methods }\end{array}$ & Intervention area outcomes & Control area outcomes \\
\hline Falkoping & $\begin{array}{l}\text { Linear regression analy- } \\
\text { sis: annual percentage } \\
\text { changes }\end{array}$ & $\begin{array}{l}\text { Initial decrease in injury rate } \\
\text { Increased over entire time span }\end{array}$ & Smaller increase in injury rates \\
\hline Lidkoping & $\begin{array}{l}\text { Linear regression analy- } \\
\text { sis }\end{array}$ & $\begin{array}{l}\text { No changes in childhood injuries } \\
\text { Downward trend }\end{array}$ & $\begin{array}{l}\text { No significant changes in childhood in- } \\
\text { juries }\end{array}$ \\
\hline Falun & $\begin{array}{l}\text { Linear regression model: } \\
\text { incidence rates }\end{array}$ & $\begin{array}{l}\text { A. No changes in targeted injuries (hospital } \\
\text { admissions) } \\
\text { B. } 23.8 \% \text { decrease in outpatient injuries }\end{array}$ & $\begin{array}{l}\text { A. Increase in "most targeted" injuries } \\
\text { B. } 13.3 \% \text { decrease in outpatient injuries }\end{array}$ \\
\hline Motala & $\begin{array}{l}\text { Interrupted time series } \\
\text { analysis: odds ratios }\end{array}$ & $\begin{array}{l}\text { Decrease in total injuries } \\
\text { Decrease in childhood, elderly, physical ac- } \\
\text { tivity, work and home related injuries } \\
\text { No change in traffic injuries }\end{array}$ & $\begin{array}{l}\text { No change in total injuries } \\
\text { No change in childhood, elderly, physical } \\
\text { activity, work or traffic related injuries }\end{array}$ \\
\hline $\begin{array}{l}\text { Skaraborg } \\
\text { Country }\end{array}$ & $\begin{array}{l}\text { Time trend analysis mod- } \\
\text { els }\end{array}$ & $\begin{array}{l}\text { Decrease in injuries in Lidkoping } \\
\text { Increase in injuries in Skovde } \\
\text { No significant changes in } 3 \text { other commu- } \\
\text { nities }\end{array}$ & $\begin{array}{l}\text { Increase in injuries in 'rest of Sweden' } \\
\text { Decrease in injuries in 'rest of Skaraborg' }\end{array}$ \\
\hline $\begin{array}{l}14 \text { Swedish } \\
\text { communities }\end{array}$ & $\begin{array}{l}\text { Poisson regression analy- } \\
\text { sis }\end{array}$ & Injury rate reductions in $7 / 14$ communities & $\begin{array}{l}\text { Injury rate reductions in } 12 / 14 \text { commu- } \\
\text { nities and overall reduction of injuries in } \\
\text { Sweden by } 5.14 \%\end{array}$ \\
\hline Harstad & $\begin{array}{l}\text { Regression analysis: rela- } \\
\text { tive risks } \\
\text { NB - relative risks for } \\
\text { traffic injuries were cal- } \\
\text { culated by reviewers us- } \\
\text { ing information provided }\end{array}$ & $\begin{array}{l}\text { Decrease in burns and scalds in children } \\
\text { Decrease in traffic injuries } \\
\text { No change in fractures in the elderly }\end{array}$ & $\begin{array}{l}\text { No change in burns and scalds in children } \\
\text { Increase in traffic injuries } \\
\text { Increase in fractures in the elderly }\end{array}$ \\
\hline Shire of Bulla & $\begin{array}{l}\text { Linear regression analy- } \\
\text { sis: incidence rates }\end{array}$ & No changes in injuries & No changes in injuries \\
\hline $\begin{array}{l}\text { Mount Isa, } \\
\text { Mackay }\end{array}$ & $\begin{array}{l}\text { Linear regression analy- } \\
\text { sis }\end{array}$ & $\begin{array}{l}\text { Decrease in both hospital admissions and } \\
\text { emergency department presentations }\end{array}$ & $\begin{array}{l}\text { Increase in both hospital admissions and } \\
\text { emergency department presentations }\end{array}$ \\
\hline Vorarlberg & Time series analysis & $\begin{array}{l}\text { Decrease in injury fatalities and increase in } \\
\text { injury hospital admissions } \\
\text { Fatalities and hospital admissions were } \\
\text { lower than would be expected compared } \\
\text { with the rest of Austria }\end{array}$ & $\begin{array}{l}\text { Decrease in injury fatalities and increase } \\
\text { in injury hospital admissions }\end{array}$ \\
\hline $\begin{array}{l}\text { New Ply- } \\
\text { mouth }\end{array}$ & Time series analysis & $\begin{array}{l}\text { Fluctuation in deaths } \\
\text { No changes in hospital admissions }\end{array}$ & Increase in hospital admissions \\
\hline
\end{tabular}


Table 2. Summary of results (Continued)
Waitakere
Logistic regression analy-
sis
No change in overall injuries
No change in overall injuries
Decrease in paediatric injuries
Increase in paediatric injuries

\section{AP PENDICES}

\section{Appendix 1. Search strategy}

\section{Search strategies August 2007}

CENTRAL (The Cochrane Library 2007, Issue 3)

MEDLINE (Ovid SP) 1950 to August (week 4) 2007

EMBASE (Ovid SP) 1980 to (week 34) August 2007

1.World Health Organization.ab,ti. or 'WHO'.ti.

2.exp World Health Organization/

3.1 or 2

4.(safe $\$$ adj1 (community or communities)).ab,ti.

5.((community or communities) adj3 (injury or injuries) adj3 prevent\$).ab,ti.

6.4 or 5

7.3 and 6

\section{PsycINFO (Ovid SP) 1806 to August (week 3) 2007}

1.(community or communities) near3 (injury or injuries)

2.safe\$ near1 (community or communities)

3.\#1 or \#2

ISI Web of Science: Social Sciences Citation Index (SSCI) 1970 to August 2007

\#1injury or injuries

$\# 2$ (community or communities) same safe

\#3World Health Organization or WHO

\#4\#1 and \#2 and \#3

\section{ZETOC (searched 30 August 2007)}

Communit* injur* safe $^{\star}$

\section{WHAT'S NEW}

\begin{tabular}{lll}
\hline Date & Event & Description \\
\hline 27 January 2009 & $\begin{array}{l}\text { New citation required and conclusions } \\
\text { have changed }\end{array}$ & Review updated: \\
& $\begin{array}{l}\text { searches updated with } 11 \text { new publications considered for in- } \\
\text { clusion; }\end{array}$ \\
& $\begin{array}{l}\text { - five new studies added; } \\
\end{array}$ \\
& - additional publications added for three existing studies; \\
& Background, Discussion and Conclusions sections amended. \\
\hline
\end{tabular}

\section{H I S T ORY}

Protocol first published: Issue 4, 2003

Review first published: Issue 2, 2005 


\begin{tabular}{lll}
\hline Date & Event & Description \\
\hline 14 May 2008 & Amended & Converted to new review format. \\
\hline 17 February 2005 & $\begin{array}{l}\text { New citation required and conclusions } \\
\text { have changed }\end{array}$ & First published version of review. \\
\hline
\end{tabular}

\section{CONTRIBUTIONS OF AUTHORS}

Anneliese Spinks was involved in the conception of the review, searching and initial screening of potential articles, co-ordinating discussion with other authors and manuscript preparation. Catherine Turner and Rod McClure each independently assessed relevant studies against the inclusion criteria and independently extracted data from the included studies and participated in editing the manuscript. Jim Nixon participated in discussion to resolve selection of studies and in the editing of the manuscript.

\section{DECLARATIONS OF INTEREST}

One of the authors of this review (Rod McClure) was involved in the evaluation of the intervention activities that were conducted in Mount Isa and Mackay and is an author on the evaluation report included as a reference for that study.

\section{SOURCES OF SUPPORT}

\section{Internal sources}

- Injury Prevention and Control (Australia) Ltd, Australia.

- University of Queensland, Australia.

\section{External sources}

- No sources of support supplied

\section{INDEX TERMS}

\section{Medical Subject Headings (MeSH)}

*Program Evaluation; Accident Prevention [methods] [standards]; Australia; Austria; Hospitalization [statistics \& numerical data]; New Zealand; Norway; Program Development [standards]; Risk Reduction Behavior; Safety Management [ ${ }^{\star}$ organization \& administration] [standards]; Sweden; World Health Organization; Wounds and Injuries [prevention \& control]

\section{MeSH check words}

Female; Humans; Male 